\title{
PENERAPAN MODEL PEMBELAJARAN KOOPERATIF GIVING QUESTION AND GETTING ANSWER UNTUK MENINGKATKAN HASIL BELAJAR ILMU PENGETAHUAN SOSIAL PADA SISWA SEKOLAH MENENGAH PERTAMA NEGERI 6 BANJARMASIN
}

\author{
KASYPUL ANWAR ${ }^{1)}$, GUSTI IRHAMNI ${ }^{2)}$ \\ Program Studi Manajemen Pendidikan, Universitas Islam Kalimantan \\ ${ }^{1)}$ kasypul.a@yahoo.com, ${ }^{2)}$ gustiirhamni69@gmail.com
}

\begin{abstract}
ABSTRAK
Peningkatan kualitas pendidikan sangat ditentukan dengan kualitas pembelajaran. Dalam hal ini guru ikut serta dalam usaha meningkatkan kualitas pembelajaran. Guru sebaiknya berperan aktif dan menempatkan kedudukannya sebagai tenaga pendidik yang profesional. Salah satu metode pembelajaran yang dapat diterapkan adalah metode pembelajaran GQGA. Metode GQGA (Giving Question and Getting Answers) adalah metode yang melibatkan siswa dalam mengulangi materi pelajaran yang telah dipelajari. Penelitian ini merupakan penelitian eksperimental dengan rancangan peneiitian Randomized Pre and Post Test Control Group Design. Masing-masing kelompok yang terdiri dari 10 orang yaitu Kelompok Perlakuan dan Kelompok Kontrol.

Hasil penelitian menunjukkan bahwa (1) Proses Penerapan model pembelajaran kooperatif tipe Giving Question And Getting Answer untuk meningkatkan Hasil Belajar Ilmu Pengetahuan Sosial Pada Siswa Sekolah Menengah Pertama Negeri 6 Banjarmasin dilakukan dengan mengevaluasi hasil pembelajaran selama 6 minggu pembelajaran; (2) Penerapan model pembelajaran kooperatif tipe Giving Question And Getting Answer dapat meningkatkan hasil belajar Ilmu Pengetahuan Sosial Pada Siswa Sekolah Menengah Pertama Negeri 6 Banjarmasin secara signifikan.
\end{abstract}

Kata Kunci: Kooperatif Giving Question And Getting Answer, Hasil Belajar

\section{ABSTRACT}

Improving the quality of education is largely determined by the quality of learning. In this case, the teacher participates in efforts to improve the quality of learning. Teachers should play an active role and position themselves as professional educators. One of the learning methods that can be applied is the GQGA learning method. The GQGA (Giving Question and Getting Answers) method is a method that involves students in repeating the subject matter that has been studied. This research is an experimental study with a randomized pre and post-test control group design. Each group consisting of 10 people, namely the Treatment Group and the Control Group.

The results show that (1) the process of implementing the cooperative learning model type Giving Question and Getting Answer to improve the Social Science Learning Outcomes in Junior High School 6 Banjarmasin is carried out by evaluating the learning outcomes for 6 weeks of learning; (2) The application of the cooperative learning model of the Giving Question And Getting Answer type can significantly improve the learning outcomes of Social Sciences in Students of 6 Banjarmasin Junior High Schools.

$\overline{\text { Keywords: Cooperative Giving Questions And Getting Answers, Learning Outcomes }}$

\section{PENDAHULUAN}

Pendidikan merupakan wadah untuk mencerdaskan kehidupan bangsa, sehingga tercipta sumber daya manusia terdidik yang mampu menghadapi perkembangan zaman yang semakin maju. Upaya untuk meningkatkan sumber daya manusia merupakan tugas besar bagi para guru dan melalui proses yang sangat panjang. Sumber daya manusia yang berkualitas diperoleh melalui pendidikan yang berkualitas. Kualitas pendidikan Indonesia berada pada peringkat ke-64 dari 120 negara di seluruh dunia berdasarkan laporan 
tahunan UNESCO (Educational For All Global Monitoring Report 2012). Hal tersebut menunjukkan bahwa kualitas pendidikan di Indonesia saat ini masih tertinggal dibandingkan dengan kualitas pendidikan di negara lain (USAID, 2013).

Peningkatan kualitas pendidikan sangat ditentukan dengan kualitas pembelajaran. Dalam hal ini guru ikut serta dalam usaha meningkatkan kualitas pembelajaran. Guru sebaiknya berperan aktif dan menempatkan kedudukannya sebagai tenaga pendidik yang profesional. Guru sebaiknya juga selalu kreatif dan inovatif dalam menggunakan metode pembelajaran agar siswa lebih mudah memahami materi yang disampaikan. Metode pembelajaran yang dipilih harus sesuai dengan materi pelajaran yang akan disampaikan agar tercapainya tujuan pembelajaran. Salah satu tujuan pembelajaran yang ingin dicapai dalam proses pembelajaran adalah hasil belajar. Asep Jihad dan Abdul Haris (2013: 15) mengemukakan bahwa salah satu tujuan pembelajaran adalah hasil belajar. Setiap proses belajar mengajar keberhasilannya diukur dari seberapa jauh hasil belajar yang dicapai oleh siswa. Keberhasilan dalam pembelajaran dapat terlaksana apabila terjadi interaksi antara guru dengan siswa.

Di dalam proses belajar mengajar guru berperan di dalam mengarahkan bagaimana proses belajar mengajar itu dilaksanakan. Karena itu guru harus dapat membuat suatu pengajaran menjadi lebih efektif juga menarik sehingga materi pelajaran yang disampaikan akan membuat siswa merasa senang dan merasa perlu untuk mempelajari bahan pelajaran tersebut. Proses belajar mengajar merupakan suatu rentetan kegiatan guru menumbuhkan organisasi proses belajar mengajar yang efektif, yang meliputi: tujuan pengajaran, pengaturan penggunaan waktu luang, pengaturan ruang dan alat perlengkapan pelajaran di kelas, serta pengelompokan siswa dalam belajar (Djamarah dan Zain, 2010). Tujuan pembelajaran tidak mudah dicapai apabila guru tidak menerapkan strategi yang tepat dalam kegiatan proses belajar mengajar, oleh karena itu guru harus mampu memilih strategi pembelajaran yang sesuai dengan tujuan pembelajaran. Metode pembelajaran yang tidak sesuai dengan materi pelajaran dan keadaan siswa dapat mengakibatkan dapat mengakibatkan motivasi belajar siswa menjadi rendah (Dimyati dan Moedjiono, 2006). Rendahnya motivasi belajar siswa dapat berdampak terhadap menurunnya hasil belajar siswa.

Pemilihan metode pembelajaran sangat penting untuk meningkatkan hasil belajar siswa, yaitu dengan menerapkan pembelajaran kooperatif. Pembelajaran kooperatif dapat dipilih untuk mencapai tujuan pembelajaran. Pembelajaran kooperatif lebih melibatkan siswa secara langsung untuk aktif dalam pembelajaran yang diharapkan dapat meningkatkan hasil belajar siswa terhadap pelajaran IPS.

Untuk itu diperlukan suatu metode pembelajaran yang dapat menciptakan suasana pembelajaran yang menyenangkan sehingga siswa menjadi tertarik di dalam mengikuti proses pembelajaran di kelas. Salah satu metode pembelajaran yang dapat diterapkan adalah metode pembelajaran GQGA. Metode GQGA (Giving Question and Getting Answers) adalah metode yang melibatkan siswa dalam mengulangi materi pelajaran yang telah dipelajari. Metode GQGA dapat melatih siswa untuk bertanya, mengemukakan pendapat, dan menjelaskan bahan pelajaran yang telah dipelajari kepada teman sekelasnya sehingga dapat meningkatkan hasil belajar siswa.

Metode Giving Question and Getting Answer dan metode Question Student Have merupakan metode kooperatif yang dapat meningkatkan hasil belajar siswa. Husaipah (2014: 4) mengemukakan bahwa penerapan metode Giving Question and Getting Answer akan membuat siswa aktif, mandiri, serta siswa dapat mengemukakan pertanyaan, sehingga dapat meningkatkan hasil belajar siswa. Metode Giving Question and Getting Answer memberikan kesempatan pada siswa untuk bertanya mengenai hal yang tidak dimengerti dan memberikan kesempatan kepada siswa untuk menjelaskan hal yang sudah dimengerti kepada temannya yang lain. Metode ini akan meningkatkan keberanian siswa dalam mengemukakan pendapatnya dan memberikan sikap saling menghargai antar siswa (Silberman, 2013: 254).

Selain metode Giving Question and Getting Answer, metode Question Student Have juga merupakan metode yang dirancang untuk mengetahui keinginan dan harapan siswa, yang diharapkan mampu meningkatkan hasil belajar siswa. Haning Vianata (2012: 2) mengemukakan bahwa salah satu metode pembelajaran yang dapat meningkatkan hasil belajar adalah metode pembelajaran Question Student Have. Metode pembelajaran Question Student Have dirancang untuk membuat siswa untuk aktif dan menyatukan pendapat dan mengukur sejauh mana siswa memahami pelajaran melalui pertanyaan tertulis.

Perbedaan antara metode Giving Question And Getting Answer dan metode Question Student Have terletak pada pembagian jumlah potongan kertas. Pada metode Giving Question And Getting Answer setiap siswa mendapatkan dua kertas, yaitu kertas untuk bertanya dan kertas untuk menjawab. Sedangkan pada metode Question Student Have siswa diberikan satu kertas, yaitu kertas untuk menuliskan pertanyaan. Persamaan metode Giving Question And Getting Answer dan metode Question Student Have terletak pada penggunaan potongan-potongan kertas sebagai media dalam proses pembelajaran. 
Pada kegiatan pendidikan terjadi hubungan fungsional antara sumber daya pendidikan dengan sumber daya manusia selaku penggeraknya. Sebagai suatu proses, penyelenggaraan kegiatan pendidikan memerlukan penanganan yang terencana dan sistematis, sehingga berbagai sumber daya pendidikan, dapat dimanfaatkan secara optimal untuk mencapai efisiensi dan efektivitas.

Castetter, W.B. (2014:198) mengkaitkan administrasi pendidikan dengan pengembangan struktur sosial yaitu: "... education administration is a sosial process that place within the context of sosial system." Berdasarkan uraian-uraian tersebut, dapat disimpulkan bahwa fungsi administrasi pendidikan merupakan alat untuk mengalokasikan dan mengintegrasi peranan maupun fasilitas, guna tercapainya tujuan sistem pendidikan.Sedangkan secara operasional, administrasi pendidikan merupakan proses mengatur hubungan manusia dengan manusia yang ada dalam sistem pendidikan tersebut. Pendapat lain menurut Engkoswara (2011: 26), administrasi pendidikan adalah optimalisasi sumber daya pendidikan yang terdiri dari manusia (murid, guru, karyawan dan sebagainya), sumber belajar, dan sumber fasilitas, serta dana, melibatkan tiga proses atau fungsi utama perilaku manusia berorganisasi yang dibagi atas perencanaan, pelaksanaan, dan pengawasan, untuk mencapai tujuan pendidikan yang telah ditetapkan secara produktif, baik untuk kepentingan perorangan, maupun untuk kepentingan lembaga. Selain pentingnya sumber belajar, juga sangat penting strategi pembelajaran.

Strategi pembelajaran adalah rangkaian kegiatan dalam proses pembelajaran yang terkait dengan pengelolaan siswa, pengelolaan guru, pengelolaan kegiatan pembelajaran, pengelolaan lingkungan belajar, pengelolaan sumber belajar dan penilaian agar pembelajaran lebih efektif dan efisien sesuai dengan tujuan pembelajaran yang ditetapkan. Strategi pembelajaran pada hakikatnya terkait dengan perencanaan atau kebijakan yang dirancang di dalam mengelola pembelajaran untuk mencapai tujuan pembelajaran yang diinginkan.

Strategi giving question and getting answers (GQGA) dikembangkan untuk melatih peserta didik memiliki kemampuan dan keterampilan dalam bertanya dan menjawab pertanyaan. Strategi giving question and getting answers (GQGA) merupakan implementasi dari strategi pembelajaran kontrukstivistik yang menempatkan siswa sebagai subyek dalam pembelajaran. Artinya, siswa mampu merekonstruksi pengetahuannya sendiri sedangkan guru hanya sebagai fasilitator saja. Strategi giving question and getting answers (GQGA) di temukan oleh Spancer Kagan, orang berkebangsaan Swiss pada tahun 1963. Strategi ini di kembangkan untuk melatih siswa memiliki kemampuan dan keterampilan bertanya dan menjawab pertanyaan, karena pada dasarnya strategi tersebut merupakan modifikasi dari metode tanya jawab dan metode ceramah yang merupakan kolaborasi dengan menggunakan potongan-potongan kertas sebagai medianya.

Kegiatan bertanya dan menjawab merupakan hal yang esensial dalam pola interaksi antara guru dan siswa. Kegiatan bertanya dan menjawab yang dilakukan oleh guru dan siswa dalam proses belajar mengajar mampu menumbuhkan pengetahuan baru pada diri siswa. Strategi giving question and getting answers (GQGA) dilakukan bersama antara metode tanya jawab dengan metode ceramah, agar siswa tidak dalam keadaan blank mind. Metode ceramah sebagai dasar agar siswa mendapatkan pengetahuan dasar (prior knowledge).

Strategi giving question and getting answer merupakan salah satu strategi meninjau ulang (reviewing strategies), yang secara bahasa memberi pertanyaan dan menerima jawaban. Ashari dalam Wilinda (2013, hlm. 27) dalam artikelnya menyebutkan strategi giving question and getting answer ditemukan oleh Spancer Kagan, orang berkebangsaan Swiss pada tahun 1963. Menurut Silberman (2009, hlm. 244) mengatakan "Strategi ini secara tidak langsung menantang siswa untuk mengingat kembali apa yang dipelajari dalam setiap topik atau unit pelajaran". Sementara itu Zaini (2009, hlm. 69) mengatakan "Strategi ini sangat baik digunakan untuk melibatkan siswa dalam mengulang materi pelajaran yang telah disampaikan".

Prinsip-prinsip strategi pembelajaran giving question and getting answer menurut Silberman (2009, hlm. 245) adalah: 1) Pemberian kartu/kertas Dalam teknik pembelajaran ini, media yang digunakan adalah kartu atau kertas dengan jenis yang berbeda dan dibagikan kepada seluruh siswa. 2) Diskusi kelompok Diskusi kelompok merupakan salah satu bentuk kegiatan belajar yang dapat meningkatkan keaktifan siswa, sebab dalam diskusi kelompok memungkinkan kerjasama antara siswa baik dengan ataupun tanoa bimbingan guru. Suasana belajar yang menimbulkan sikap kerjasama antara siswa dalam memecahkan masalah mempunyai keuntungan yang diperoleh yaitu: 3) Presentasi Presentasi siswa di depan kelas bertujuan untuk menguji kemampuan siswa untuk menyampaikan ide atau pendapat setelah mereka memperoleh pengalaman belajarnya. Presentasi siswa juga dapat meningkatkan kepercayaan diri siswa untuk tampil dan berkomunikasi di depan kelas atau di luar kelas. Siswa diajarkan agar tidak takut salah sebelum mencoba. Siswa harus siap untuk menerima sanggahan atau pertanyaan dari siswa lain karena dalam sesi presentasi akan ada tanya jawab oleh siswa. 
Prinsip-prinsip strategi pembelajaran giving question and getting answer berkaitan dengan memberikan kertas/kartu dengan jenis pertanyaan dan jawaban kepada tiap siswa sebagai media yang digunakan dalam teknik pembelajaran, diskusi kelompok sebagai kegiatan belajar kerjasama antara siswa dimana saling berinteraksi dalam mengambil keputusan, dan presentasi untuk menyampaikan pendapat setelah materi BUMN disampaikan berupa pertanyaan maupun jawaban atas pertanyaan yang di berikan oleh kelompok lain.Strategi pembelajaran dan proses belajar akan terlihat nyata dari hasil elajar yang diperoleh.

Proses belajar terjadi karena adanya suatu tujuan yang ingin dicapai. Tujuan yang dimaksud adalah berupa hasil belajar. Hasil belajar harus menunjukkan suatu perubahan tingkah laku yang bersifat menetap, fungsional, positif dan disadari. Perwujudan hasil belajar akan selalu berkaitan dengan kegiatan evaluasi. Untuk itu diperlukan teknik dan prosedur evaluasi belajar yang dapat menilai secara efektif proses dan hasil belajar.

Menurut Sri Anitah (2008:2.19) hasil belajar yang berkaitan dengan kemampuan berfikir kritis dan ilmiah siswa Sekolah Dasar, dapat dikaji berdasarkan : a. Kemampuan membaca, mengamati dan atau menyimak apa yang dijelaskan atau diinformasikan. b. Kemampuan mengidentifikasi atau membuat ssejumlah (sub-sub) pertanyaan berdasarkan substansi yang dibaca, diamati dan atau didengar. c. Kemampuan mengorganisasikan hasil-hasil identifikasi dan mengkaji dari sudut persamaan dan perbedaan. d. Kemampuan melakukan kajian secara menyeluruh. H.M. Surya (2008:8.6) menyatakan hasil belajar ditandai dengan perubahan tingkah laku secara keseluruhan. Perubahan tingkah laku sebagai hasil belajar meliputi aspek tingkah laku kognitif, konotatif, afektif atau motorik. Belajar yang hanya menghasilkan perubahan satu atau dua aspek tingkah laku saja disebut belajar sebagian dan bukan belajar lengkap.

Hasil belajar adalah kemampuan-kemampuan yang dimiliki peserta didik setelah ia menerima pengalaman belajarnya. Howard Kingsley membagi tiga macam hasil belajar, yakni (a) keterampilan dan kebiasaan, (b) pengetahuan dan pengertian, (c) sikap dan cita-cita. Masing-masing jenis hasil belajar dapat diisi dengan bahan yang telah ditetapkan dalam kurikulum. Adapun Gagne membagi lima kategori hasil belajar, yakni (a) informasi verbal, (b) keterampilan intelektual, (c) strategi kognitif, (d) sikap, dan (e) keterampilan motoris. Dalam sistem pendidikan nasional rumusan tujuan pendidikan, baik tujuan kurikuler, tujuan institusional maupun tujuan instruksional, menggunakan klasifikasi hasil belajar dari Benyamin Bloom yang secara garis besar membaginya menjadi tiga ranah, yakni ranah kognitif, ranah afektif dan ranah psikomotoris.

\section{Rumusan Masalah}

Adapun rumusan masalah penelitian ini yaitu "Bagaimana penerapan model pembelajaran kooperatif tipe Giving Question And Getting Answer untuk meningkatkan Hasil Belajar Ilmu Pengetahuan Sosial Pada Siswa Sekolah Menengah Pertama Negeri 6 Banjarmasin”.

\section{Tujuan Penelitian}

Adapun tujuan penelitian ini yaitu untuk mendeskripsikan penerapan model pembelajaran kooperatif tipe Giving Question And Getting Answer untuk meningkatkan Hasil Belajar Ilmu Pengetahuan Sosial Pada Siswa Sekolah Menengah Pertama Negeri 6 Banjarmasin.

\section{METODE PENELITIAN}

Penelitian ini merupakan penelitian eksperimental dengan rancangan peneiitian Randomized Pre and Post Test Control Group Design (Pocock, 2008). Masing-masing kelompok yang terdiri dari 10 orang yaitu Kelompok Perlakuan dan Kelompok Kontrol. Kedua kelompok diberikan tes awal yang berupa hasil pembelajaran. Setelah tes awal kedua kelompok diberikan pelatihan dengan perlakuan yang berbeda secara bersamaan. Kelompok Perlakuan diberikan pelatihan GQGA dan Kelompok Kontrol diberikan pelatihan tanpa GQGA. Kemudian masing-masing kelompok diobservasi sama dengan tes awal yaitu hasil belajar.

Jenis data yang diperlukan dalam penelitian ini adalah data primer. Dalam peneltian ini data primer diperoleh langsung pengamatan yang dilakukan di SMP N 6 Banjarmasin. Data yang diperoleh sebelum maupun setelah pelatihan dianalisis dengan menggunakan langkah-langkah sebagai berikut (Sastroasmoro dan Ismail, 2010) :

1. Statistik Diskriptif digunakan untuk mendeskripsikan umur dan jenis kelamin siswa

2. Uji Normalitas data hasil kecepatan tendangan dengan Saphiro Wilk Test yang bertujuan untuk mengetahui distribusi data masing-masing kelompok perlakuan dari kedua kelompok pelatihan baik sebelum maupun sesudah pelatihan. Batas kemaknaan adalah $95 \%(\alpha=0,05)$. 
3. Uji Homogenitas data dengan menggunakan Levene Test, bertujuan untuk mengetahui variasi data hasil pemahaman pada kedua kelompok baik sebelum maupun sesudah pelatihan. Batas kemaknaan yang digunakan adalah $\alpha=0,05$.

4. Uji Komparasi Data dengan t-independent test. Uji ini adalah uji t tidak berpasangan yang dipakai untuk menganalisis perbedaan hasil belajar antar kelompok perlakuan, baik sebelum maupun sesudah perlakuan.

5. Uji Komparasi Data dengan t-paired test. Uji ini adalah uji $\mathrm{t}$ berpasangan, yang dipakai untuk menganalisis perbedaan hasil belajar antara sebelum dan sesudah pelatihan pada kedua kelompok perlakuan.

\section{HASIL DAN PEMBAHASAN}

\section{A. Analisis Data}

Penelitian yang telah dilaksanakan di SMP N 6 Banjarmasin, selama enam minggu menggunakan rencana eksperimental terhadap dua kelompok penelitian. Subjek penelitian berjumlah 20 orang siswa, yang di bagi menjadi dua kelompok, masing-masing kelompok terdiri dari sepuluh orang. Kelompok Perlakuan di berikan pelatihan GQGA dan Kelompok Kontrol di berikan pelatihan tanpa penambahan GQGA.

\section{B. Uji Normalitas Dan Homogenitas Hasil Belajar}

Sebagai persyarat untuk menentukan uji statistik yang akan di gunakan maka dilakukan uji normalitas dan homogenitas data hasil belajar sebelum dan sesudah penelitian. Uji normalitas dengan menggunakan uji saphiro wilk test. Uji homogenitas menggunakan Levene Test, untuk semua variabel bebas dan tergantung (Tabel .1).

Tabel 1. Hasil Uji Normalitas Dan Homogenitas Data Pembelajaran GQGA Siswa SMP N 6 Banjarmasin

\begin{tabular}{|l|l|l|l|}
\hline \multirow{2}{*}{ Kecepatan tendangan } & \multicolumn{2}{|l|}{ Uji normalitas (shapiro wilk- test) } & \multirow{2}{*}{ Homogenitas Levene Test } \\
\cline { 2 - 4 } & Kelompok Perlakuan & $\begin{array}{l}\text { Kelompok } \\
\text { Kontrol }\end{array}$ & 0,795 \\
\hline Hasil belajar sebelum pelatihan & 0,451 & 0,132 \\
\hline Hasil belajar setelah pelatihan & 0,365 & 0,730 & 0,130 \\
\hline
\end{tabular}

Berdasarkan hasil uji normalitas (shapiro wilk-test) dan uji homogenitas (levene test) data hasil belajar sebelum dan sesudah pembelajaran GQGA pada kedua kelompok menunjukan bahwa dari kedua uji tersebut memiliki nilai $p>0,05$, yang berarti data pembelajaran GQGA sebelum dan setelah pelatihan berdistribusi normal. Oleh karena itu uji parametrik dapat dilanjutkan. Uji homogenitas menunjukkan sebelum pelatihan dan sesudah pelatihan antara kedua kelompok adalah homogen $(p>0,05)$.

\section{Uji Beda Rerata Hasil Belajar Antar Kelompok Perlakuan}

Uji beda rerata bertujuan untuk membandingan rerata hasil belajar antar kelompok pelatihan baik sebelum maupun sesudah pelatihan. Hasil analisis kemaknaan dengan uji t-independent (Tabel 2).

Tabel 2. Hasil Uji Beda Rerata Hasil Belajar Sebelum dan Sesudah Pelatihan Antar Ke Dua Kelompok

\begin{tabular}{|c|c|c|c|c|}
\hline & $\mathrm{n}$ & Rerata $\pm \mathrm{SB}$ & $\mathrm{t}$ & $\mathrm{p}$ \\
\hline Sebelum pembelajaran Kelompok Perlakuan & 10 & $0,617 \pm 0,07$ & \multirow[b]{2}{*}{0,515} & \multirow[b]{2}{*}{0,613} \\
\hline Sebelum pembelajaran Kelompok Kontrol & 10 & $0,604 \pm 0,04$ & & \\
\hline Sesudah pembelajaran Kelompok Perlakuan & 10 & $0,467 \pm 0,06$ & \multirow[b]{2}{*}{$-2,944$} & \multirow[b]{2}{*}{0,087} \\
\hline Sesudah pembelajaran Kelompok Kontrol & 10 & $0,536 \pm 0,04$ & & \\
\hline
\end{tabular}

Tabel 2 menunjukan bahwa rerata hasil belajar antar kedua kelompok pelatihan memiliki nilai $\mathrm{p}>$ 0,05, dimana nilai p pada Kelompok Perlakuan sebesar 0,613, dan Kelompok Kontrol sebesar 0,087 ( $>0,05)$, hal ini berarti tidak terdapat perbedaan yang signifikan pada peningkatan hasil belajar antara Kelompok Perlakuan GQGA dan Kelompok Kontrol.

\section{Uji Beda Rerata Peningkatan Hasil Belajar Antara Sebelum Dan Sesudah Pelatihan}

Untuk mengetahui perbedaan rerata peningkatan hasil belajar sebelum dan sesudah pelatihan pada masing-masing kelompok di gunakan uji $t$-paired (berpasangan) pada batas kemaknaan $\propto=0,05$ (Tabel 3). 
Tabel 3. Hasil Uji Beda Rereta Peningkatan Hasil Belajar Sebelum Dan Sesudah Pelatihan

\begin{tabular}{|l|l|l|l|l|}
\hline \multirow{2}{*}{ Kelompok } & \multicolumn{2}{|l|}{ Hasil Belajar } & \multirow{2}{*}{ t } & \multirow{2}{*}{ p } \\
\cline { 2 - 3 } & Sebelum pelatihan & Sesudah latihan & & \multicolumn{1}{|c|}{0,000} \\
\hline Kelompok Perlakuan & $0,617 \pm 0,07$ & $0,467 \pm 0,06$ & 30,339 & 0,000 \\
\hline Kelompok Kontrol & $0,604 \pm 0,04$ & $0,536 \pm 0,04$ & 17,493 & 0,000 \\
\hline
\end{tabular}

Tabel 3 menunjukan beda rerata peningkatan hasil belajar sebelum dan sesudah pelatihan pada masing-masing kelompok memiliki nilai $\mathrm{p}<0,05$. Hal ini berarti pada masing-masing kelompok terjadi peningkatan hasil belajar antara sebelum dan sesudah pelatihan bermakna. Dengan demikian penerapan model pembelajaran kooperatif giving question and getting answer dapat meningkatkan hasil belajar ilmu pengetahuan sosial pada siswa Sekolah Menengah Pertama Negeri 6 Banjarmasin. Selanjutnya persentase peningkatan hasil belajar setelah pelatihan selama enam minggu pada kedua kelompok pelatihan (Tabel 4).

Tabel 4. Persentase Peningkatan Hasil Belajar Sesudah Pelatihan

\begin{tabular}{|l|l|l|}
\hline \multicolumn{1}{|c|}{ Hasil analisis } & \multicolumn{1}{|c|}{ Kelompok Perlakuan } & Kelompok Kontrol \\
\hline Hasil belajar sebelum pelatihan & 0,617 & 0,604 \\
\hline Hasil belajar sesudah pelatihan & 0,467 & 0,536 \\
\hline Peningkatan hasil belajar & 0,15 & 0,068 \\
\hline Persentase (\%) & $24,31 \%$ & $11,26 \%$ \\
\hline
\end{tabular}

Dari Tabel 4. kedua pelatihan meningkatkan hasil belajar, dimana pelatihan Kelompok Perlakuan terjadi peningkatan sebesar $24,31 \%$ dan Kelompok Kontrol terjadi peningkatan sebesar $11,26 \%$. Hal ini menunjukkan bahwa penerapan model pembelajaran kooperatif giving question and getting answer lebih meningkatkan hasil belajar dari pada pelatihan GQGA.

\section{E. Uji Beda Rerata Hasil Belajar Antar Kelompok Perlakuan}

Berdasarkan hasil uji beda rerata hasil belajar antara Kelompok Perlakuan dan Kelompok Kontrol didapatkan hasil pada Kelompok Perlakuan sebelum pembelajaran 0,617 \pm 0,07 dan setelah pembelajaran $0,467 \pm 0,06$. Sedangkan pada Kelompok Kontrol hasil belajar sebelum pelatihan 0,604 $\pm 0,04$ dan setelah pembelajaran 0,536 $\pm 0,04$. Hal ini menunjukkan bahwa baik pada Kelompok Perlakuan maupun Kelompok Kontrol, pembelajaran sama-sama dapat meningkatkan hasil belajar. Hal ini berarti penerapan model pembelajaran kooperatif giving question and getting answer dapat meningkatkan hasil belajar ilmu pengetahuan sosial pada siswa Sekolah Menengah Pertama Negeri 6 Banjarmasin. Namun jika dibandingkan perbedaan peningkatan hasil belajar ini ternyata tidak signifikan. Hal ini bisa dilihat dari nilai $p$-value dimana sebelum pelatihan nilai $p$-value ini sebesar $0,613(\mathrm{p}>0,05)$ dan setelah pelatihan nilai $p$-value sebesar 0,087 ( $p>0,05)$, yang menunjukkan kondisi yang tidak signifikan.

\section{F. Pengaruh Penerapan Model Pembelajaran Kooperatif Giving Question And Getting Answer Untuk Meningkatkan Hasil Belajar}

Untuk mengetahui pengaruh penerapan model pembelajaran kooperatif giving question and getting answer dilihat dari nilai $p$-value masing-masing kelompok (Tabel 2). Pada Kelompok Perlakuan diperoleh nilai $p$-value sebesar $0,000(\mathrm{p}<0,05)$ yang berarti penerapan model pembelajaran kooperatif giving question and getting answer berpengaruh positif atau dapat meningkatkan hasil belajar. Pada Kelompok Kontrol diperoleh nilai $p$-value sebesar 0,000 yang berarti pembelajaran tanpa GQGA berpengaruh positif atau dapat meningkatkan hasil belajar pada Kelompok Kontrol.

Persentase peningkatan hasil belajar sesudah pelatihan baik untuk Kelompok Perlakuan maupun Kelompok Kontrol dapat dilihat pada Tabel 4.4. Dari tabel ini ditunjukkan bahwa peningkatan hasil belajar pada Kelompok Perlakuan meningkat dari 0,617 sebelum pelatihan menjadi 0,467 setelah pelatihan atau mengalami peningkatan sebesar 0,15 (meningkat 24,31\%). Pada Kelompok Kontrol peningkatan hasil belajar meningkat dari 0,604 sebelum pelatihan menjadi 0,536 setelah pelatihan atau mengalami peningkatan sebesar 0,068 (meningkat 11,26\%).

Metode Giving Question and Getting Answers (GQGA) adalah salah satu teknik instruksional dari belajar aktif (active learning). Metode ini memberikan kesempatan pada siswa untuk bertanya mengenai hal yang tidak dimengerti dan memberikan kesempatan kepada siswa untuk menjelaskan hal yang sudah dimengerti kepada temannya yang lain. Metode ini dapat meningkatkan keberanian siswa dalam mengemukakan pendapatnya dan memberikan sikap saling menghargai antar siswa (Yatim, 2009).

Metode GQGA ini dapat menciptakan suasana pembelajaran yang aktif dan menyenangkan. Sehingga siswa menjadi termotivasi di dalam mengikuti proses pembelajaran di kelas. Hal ini dapat berdampak terhadap peningkatan hasil belajar siswa. Selain itu, penghargaan kelompok juga merupakan salah satu faktor 
meningkatnya hasil belajar siswa. Pemberian penghargaan kelompok dapat membuat siswa menjadi lebih bersemangat untuk mencapai nilai tertinggi.

Pembelajaran yang menggunakan metode Giving Question And Getting Answer lebih unggul peningkatannya disebabkan karena metode ini memberikan kesempatan pada siswa untuk bertanya hal yang tidak dimengerti dan memberikan kesempatan kepada siswa untuk menjelaskan hal yang sudah dimengerti kepada siswa lainnya, sehingga hasil belajar yang diperoleh siswa dapat meningkat.

\section{PENUTUP}

\section{Simpulan}

Berdasarkan rumusan masalah, tujuan penelitian dan hipotesis penelitian serta hasil penelitian dan pembahasan, maka dapat disimpulkan hal-hal sebagai berikut:

1. Proses Penerapan model pembelajaran kooperatif tipe Giving Question And Getting Answer untuk meningkatkan Hasil Belajar Ilmu Pengetahuan Sosial Pada Siswa Sekolah Menengah Pertama Negeri 6 Banjarmasin dilakukan dengan mengevaluasi hasil pembelajaran selama 6 minggu pembelajaran

2. Penerapan model pembelajaran kooperatif tipe Giving Question And Getting Answer dapat meningkatkan hasil belajar Ilmu Pengetahuan Sosial Pada Siswa Sekolah Menengah Pertama Negeri 6 Banjarmasin secara signifikan.

\section{Saran}

Berdasarkan kesimpulan di atas, maka saran-saran yang dapat diberikan melalui hasil penelitian ini adalah sebagai berikut:

1. Sebaiknya penerapan metode GQGA dapat dilaksanakan oleh guru di kelas. Karena penerapan metode pembelajaran GQGA di dalam proses pembelajaran dapat meningkatkan kompetensi guru.

2. Sebaiknya di dalam penerapan metode pembelajaran GQGA lebih memperhatikan manajemen waktu agar proses pembelajaran berlangsung efektif.

\section{DAFTAR PUSTAKA}

Arikunto, Suharsimi. (2010). Penelitian Tindakan Kelas. Jakarta: PT. Bumi Aksara.

Asep Jihad dan Abdul Haris. (2013). Evaluasi Pembelajaran. Yogyakarta: Multi Pressindo

Dimayati dan Mudjiono. (2006). Belajar dan Pembelajaran. Jakarta: Renika Cipta.

Djamarah dan Zain. (2010). Strategi Belajar Mengajar. Jakarta: Rineka Cipta.

Majid, A. (2006). Perencanaan Pembelajaran Mengembangkan Standar Kompetensi Guru. Bandung: Remaja Rosdakarya.

Sanjaya, Wina. (2011). Strategi Pembelajaran Berorientasi Standar Proses Pendidikan. Jakarta: Prenada Media Group.

Sudjana, Nana. (2012). Penilaian Hasil Proses Belajar Mengajar, Bandung:Remaja Rosdakarya: Bandung.

Suprijono, Agus. (2009). Cooperative Learning: Teori dan Aplikasi Paikem. Yogjakarta: Pustaka Pelajar.

Suryosubroto. (2009). Proses Belajar Mengajar di Sekolah. Jakarta: Rineka Cipta.

Wiersma, William. (2009). Research Method in Education: on Introduction. USA: Pearson.

Yanti Herlianti. (2006). Tanya Jawab Seputar Penelitian Pendidikan Sains. Jakarta: UIN Syarif Hidayatullah

Yatim Riyanto. (2009). Paradigma Baru Pembelajaran. Jakarta: Kencana Perdana Media Group. 